\title{
Dynamic recycling of gaseous elemental mercury in the boundary layer of the Antarctic Plateau
}

\author{
A. Dommergue ${ }^{1}$, M. Barret ${ }^{1}$, J. Courteaud ${ }^{1}$, P. Cristofanelli ${ }^{2}$, C. P. Ferrari ${ }^{1}$, and H. Gallée ${ }^{1}$ \\ ${ }^{1}$ UJF - Grenoble 1/CNRS, Laboratoire de Glaciologie et Géophysique de \\ l'Environnement (LGGE) UMR5183, Grenoble, 38041, France \\ ${ }^{2}$ Institute for Atmospheric Science and Climate, National Research Council, Bologna, Italy
}

Correspondence to: A. Dommergue (aurelien.dommergue@lgge.obs.ujf-grenoble.fr)

Received: 21 June 2012 - Published in Atmos. Chem. Phys. Discuss.: 23 July 2012

Revised: 7 November 2012 - Accepted: 8 November 2012 - Published: 21 November 2012

\begin{abstract}
Gaseous elemental mercury $\left(\mathrm{Hg}^{0}\right)$ was investigated in the troposphere and in the interstitial air extracted from the snow at Dome Concordia station (alt. $3320 \mathrm{~m}$ ) on the Antarctic Plateau during January 2009. Measurements and modeling studies showed evidence of a very dynamic and daily cycling of $\mathrm{Hg}^{0}$ inside the mixing layer with a range of values from $0.2 \mathrm{ng} \mathrm{m}^{-3}$ up to $2.3 \mathrm{ng} \mathrm{m}^{-3}$. During low solar irradiation periods, fast $\mathrm{Hg}^{0}$ oxidation processes in a confined layer were suspected. Unexpectedly high $\mathrm{Hg}^{0}$ concentrations for such a remote place were measured under higher solar irradiation due to snow photochemistry. We suggest that a daily cycling of reemission/oxidation occurs during summer within the mixing layer at Dome Concordia.

$\mathrm{Hg}^{0}$ concentrations showed a negative correlation with ozone mixing ratios, which contrasts with atmospheric mercury depletion events observed during the Arctic spring. Unlike previous Antarctic studies, we think that atmospheric $\mathrm{Hg}^{0}$ removal may not be the result of advection processes. The daily and dramatic $\mathrm{Hg}^{0}$ losses could be a consequence of surface or snow induced oxidation pathways. It remains however unclear whether halogens are involved. The cycling of other oxidants should be investigated together with $\mathrm{Hg}$ species in order to clarify the complex reactivity on the Antarctic plateau.
\end{abstract}

\section{Introduction}

Gaseous elemental mercury $\left(\mathrm{Hg}^{0}\right)$ is the most abundant form of mercury $(\mathrm{Hg})$ in the troposphere with a background concentration of approximately $1.5 \mathrm{ng} \mathrm{m}^{-3}$ in the Northern
Hemisphere and $1.1 \mathrm{ng} \mathrm{m}^{-3}$ in the Southern Hemisphere (Sprovieri et al., 2010). $\mathrm{Hg}^{0}$ is also thought to have a tropospheric residence time of about $1 \mathrm{yr}$, which means that it can be globally transported far from its emission sources (Selin et al., 2007). Oxidized $\mathrm{Hg}$ compounds, such as the operationally defined reactive gaseous $\mathrm{Hg}(\mathrm{RGM})$ and $\mathrm{Hg}$ associated with airborne particulate matter $(\mathrm{HgP})$ are normally found at much lower concentrations (in the $\mathrm{pg} \mathrm{m}^{-3}$ range) in the troposphere. The atmospheric lifetime of $\mathrm{Hg}^{0}$ dramatically decreases to a few hours during fast oxidation processes involving bromine radicals as observed in various coastal locations in the Arctic (Steffen et al., 2008) and in Antarctica (Ebinghaus et al., 2002; Sprovieri et al., 2002; Brooks et al., 2008b) during springtime.

To date, research activities dealing with $\mathrm{Hg}$ in polar regions have focused primarily on the Northern Hemisphere troposphere, whereas the atmospheric cycling of $\mathrm{Hg}$ in the Antarctic, including the impact of the Antarctic continent on the global geochemical cycle of $\mathrm{Hg}$, have not been explored in great detail (Dommergue et al., 2010). Antarctica, which is seven times larger than Greenland, has been considered a chemically-inactive and cold sink, where atmospheric species, including $\mathrm{Hg}$, are buried in the ice-cap. However, recent studies have shown that the inner plateau is a highly oxidizing area (Eisele et al., 2008) and that some compounds, such as nitrogen in the form of nitrate, may undergo multiple cycles between the snow surface and the overlying atmosphere (Davis et al., 2008). In particular, the behavior of atmospheric $\mathrm{Hg}$ on the high altitude Antarctic Plateau (several millions of $\mathrm{km}^{2}$ with an elevation above $2 \mathrm{~km}$ ) is an open and vast field of research. To date, only one atmospheric 
study has been carried out with modern on-line instruments on the Antarctic Plateau at South Pole $\left(90^{\circ} \mathrm{S}\right)$ (Brooks et al., 2008a). The authors report an unusual $\mathrm{Hg}$ cycle with high levels of oxidized $\mathrm{Hg}$ species and high $\mathrm{Hg}$ deposition on snow surfaces. The detailed mechanisms and the compounds involved in this reactivity remain uncertain. It highlights the fact that investigating the air/snow interface is essential for our comprehension of $\mathrm{Hg}$ cycling.

After two decades of intensive research on atmospheric $\mathrm{Hg}$ in the Arctic, we are now facing a new research challenge in Antarctica. The reactivity of $\mathrm{Hg}$ on the Antarctic Plateau has to be further explored in order to provide new data for understanding the global atmospheric $\mathrm{Hg}$ reactivity and to improve reactivity and deposition models (Selin et al., 2007). It is also important to understand the role of the snow on the overlying atmosphere. Atmospheric measurements on the Antarctic ice cap will also be useful to improve our interpretation of ice core data (Vandal et al., 1993; Jitaru et al., 2009).

To further develop our understanding of the physicochemical processes involving $\mathrm{Hg}$ over this large area of the planet, we report results from the summer 2009 atmospheric campaign at Dome Concordia (DC) station $\left(75^{\circ} \mathrm{S}, 123^{\circ} \mathrm{E}\right)$. Measurements of $\mathrm{Hg}^{0}$ both in the snowpack interstitial air (SIA) and in the overlying atmosphere were conducted.

\section{Methods}

\subsection{Tropospheric measurements}

This study was conducted at Dome Concordia station $\left(75^{\circ} 06^{\prime} \mathrm{S}, 123^{\circ} 20^{\prime} \mathrm{E}, 3320 \mathrm{~m}\right.$ above sea level) from 22 to 30 January 2009. Dome Concordia station (DC) is located $1100 \mathrm{~km}$ away from the nearest coast of East Antarctica as shown in Fig. 1. During this study, there was $24 \mathrm{~h}$ of sunlight. Local time $(\mathrm{UTC}+8)$ is used for convenience throughout the paper.

To minimize contamination from the station, $\mathrm{Hg}^{0}$ measurements were performed in an upwind area that is $800 \mathrm{~m}$ south of the station. We sampled ambient air 20 and $200 \mathrm{~cm}$ above the snow surface through a clean PTFE line. We used a Tekran 2537A analyzer for the continuous monitoring of $\mathrm{Hg}^{0} \cdot \mathrm{Hg}^{0}$ in the pre-filtered air stream (soda lime trap and $0.2 \mu \mathrm{m}$ PTFE filter) was alternatively collected on two gold cartridges at a flow rate of $1.0 \mathrm{~L} \mathrm{~min}^{-1} . \mathrm{Hg}^{0}$ was thermally desorbed and detected by cold vapor atomic fluorescence spectrometry at $253.7 \mathrm{~nm}$. The dual cartridge system makes continuous measurements with a collection time which was set to $10 \mathrm{~min}$. The analyzer was calibrated every $24 \mathrm{~h}$ using an internal automatic permeation source injection. We also performed external calibrations by injection of a known amount of $\mathrm{Hg}$ vapors before and after the field campaign. With this configuration mode, a detection limit of about $0.1 \mathrm{ng} \mathrm{m}^{-3}$ is expected.
During the same period, we also measured continuously the concentration of $\mathrm{Hg}^{0}$ in snow interstitial air (SIA) at depths of 40,80, 120 and $160 \mathrm{~cm}$ below the snow surface. GAMAS probes (Gaseous Mercury in Interstitial Air in Snow, Dommergue et al., 2003a) were connected to the Tekran 2537 analyzer. A heated 9-port solenoid valve (2 inlets in the atmosphere and 4 inside the snowpack are presented here) performed an alternate sampling of each inlet every $10 \mathrm{~min}$. Blanks of the probes and of the sampling system were performed using $\mathrm{Hg}$-free air supplied by an activated charcoal cartridge. As discussed in detail elsewhere (Dommergue et al., 2003b), the continuous sampling of interstitial air is subject to some artifacts. We tried to minimize them using the lowest possible flow rate $\left(1 \mathrm{~L} \mathrm{~min}^{-1}\right)$ and a short sampling time at each depth. The nature of the snowpack itself generates uncertainties on the origin of the sampled air. As a consequence, our measurements give us some information on the existence of physico-chemical processes inside the snowpack but they are not accurate enough to identify the exact spatial origin of $\mathrm{Hg}^{0}$.

Ozone $\left(\mathrm{O}_{3}\right)$ measurements were continuously performed with a UV absorption monitor (Thermo Electron Corporation model 49I, Franklin, MA). The steel inlet of the sampling line was located at $5 \mathrm{~m}$ above the ground level in the chemically clean area. The data collected at 30 -s intervals are reported as 30-min averages.

Meteorological data including continuous measurements of vertical gradients of wind and temperatures were available at the American Tower that is located $600 \mathrm{~m}$ north west of our $\mathrm{Hg}$ measurement site. Continuous measurements were performed at 6 heights $(3.5,10.6,18,25.3,32.7$ and $41.9 \mathrm{~m})$ and are reported as 30-min averages (Genthon et al., 2010, 2012).

\subsection{Snow sampling and analysis}

Snow samples were collected daily at DC and on the logistic trail between DC and the coastal site of Dumont d'Urville station $\left(60^{\circ} 40^{\prime} \mathrm{S}, 140^{\circ} 01^{\prime} \mathrm{E}, 40 \mathrm{~m}\right.$ above the sea level, Fig. 1) from 2 to 11 February. The samples were immediately stored in the dark at $-20^{\circ} \mathrm{C}$ until analyzed. We used acid cleaned PTFE $250 \mathrm{~mL}$ bottles and clean sampling procedures. Field blanks were taken by opening and closing two bottles that contained total $\mathrm{Hg}$ - free water. These blanks were transported back to the laboratory together with all the snow samples. Total $\mathrm{Hg}$ (THg) in snow samples and field blanks was measured with a Tekran Model 2600 using USEPA method 1631 revision E. Samples were oxidized with $0.5 \% v / v \mathrm{BrCl}$ to preserve divalent $\mathrm{Hg}$ in solution and to digest strongly bound $\mathrm{Hg}(\mathrm{II})$ complexes. Excess $\mathrm{BrCl}$ was neutralized with pre-purified hydroxylamine hydrochloride. The sample was automatically injected together with $\mathrm{SnCl}_{2}$, into a reaction vessel, reducing $\mathrm{Hg}$ (II) to $\mathrm{Hg}^{0}$. $\mathrm{Hg}^{0}$ was carried in an argon stream to two online gold traps. After thermal desorption, $\mathrm{Hg}^{0}$ was detected by atomic fluorescence spectrometry. 


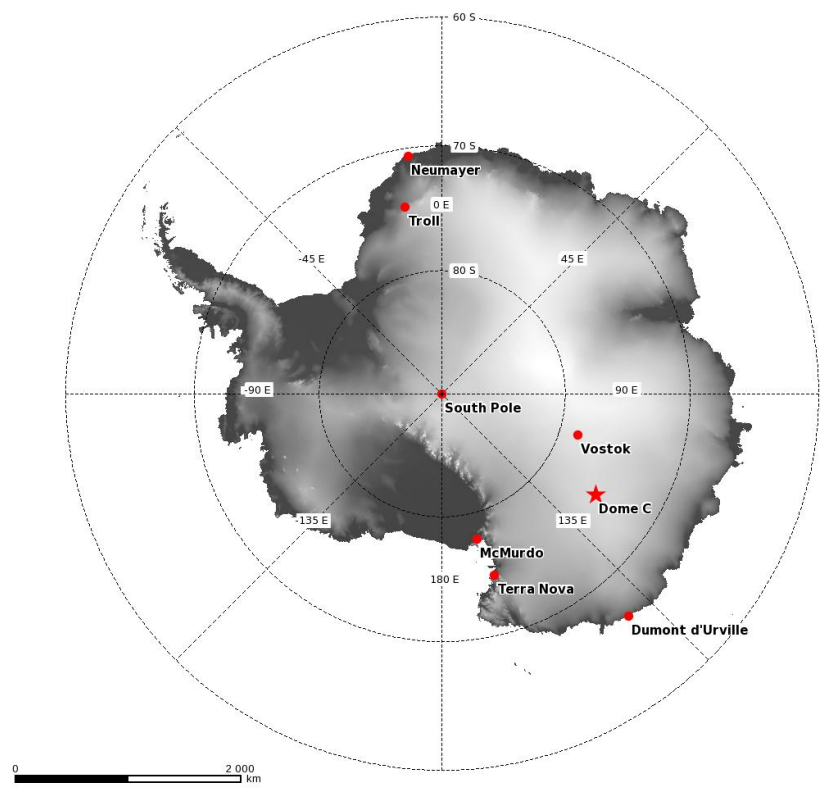

Fig. 1. Antarctic map with the location of major scientific stations where atmospheric $\mathrm{Hg}$ concentrations have been measured.

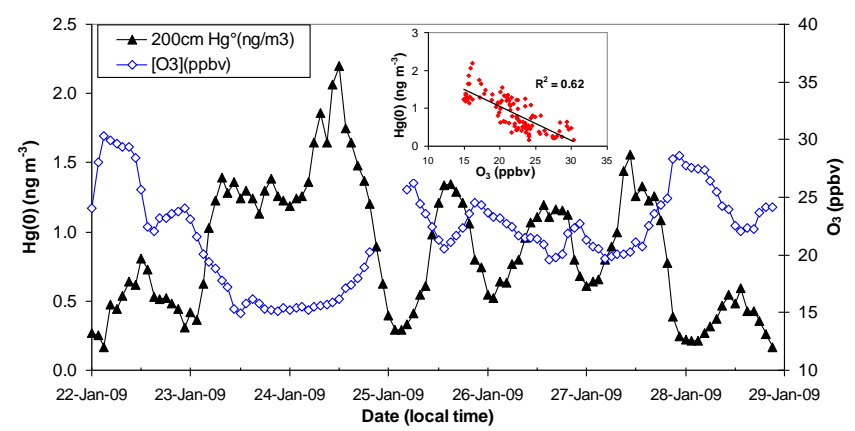

Fig. 2. $\mathrm{Hg}^{0}$ measurements (black triangles) and ozone concentrations (blue line) measured at 200 and $500 \mathrm{~cm}$ respectively above the snow surface at DC in 2009. The negative linear correlation between ozone and $\mathrm{Hg}^{0}$ is shown as an inset graph.

The Tekran Model 2600 was calibrated daily with the NIST SRM-1641d Hg standard. The limit of detection, calculated as 10 times the standard deviation of a set of 10 analytical blanks was $0.3 \mathrm{ng} \mathrm{L}^{-1}$ and relative accuracy was determined to be $\pm 8 \%$ using a certified reference material (ORMS-4, National Research Council Canada). All samples were analyzed in triplicate.

Field blanks obtained at DC contained unexpectedly high levels of $\mathrm{THg}\left(\sim 100 \mathrm{ng} \mathrm{L}^{-1}\right)$. We were forced to discard the whole set of data. The second batch of bottles, which was used to collect snow samples on the logistic trail, did not show any contamination. We will use this data set in the following sections.

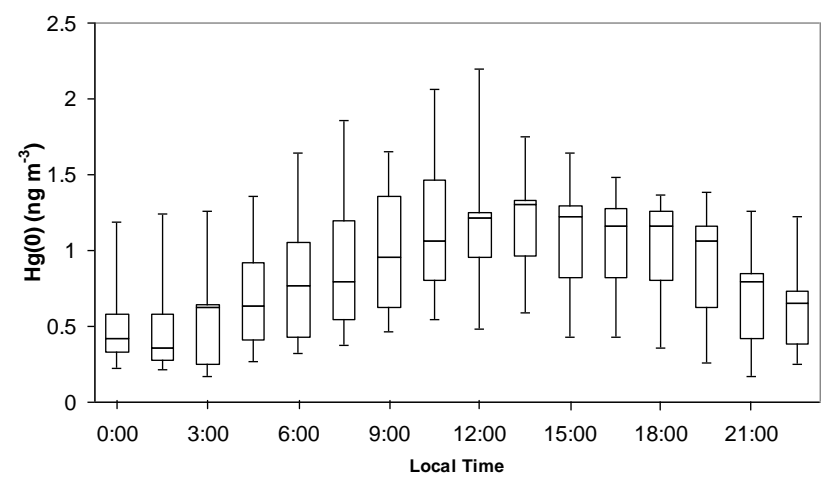

Fig. 3. Box and whisker plot of the average daily cycle for atmospheric $\mathrm{Hg}^{0}$ concentrations at DC in 90-min bins. Boxes extend from 25 to $75 \%$ quartiles; the middle line represents the median value. The whiskers extend from Min to Max values.

\subsection{Modeling of the mixing layer height}

The Antarctic plateau is characterized by strong surface temperature variations and by the development of a very shallow nighttime boundary layer that can significantly impact the vertical mixing of chemical species (Schwerdtfeger, 1984; Garratt, 1994). When the solar irradiation is low at night, the snow surface is colder than the overlying atmosphere. This thermal stratification associated with horizontal wind speed stratification prevents any vertical mixing. Conversely, the surface temperature rises as the solar irradiation increases. Turbulence starts to develop from the surface leading to fast vertical mixing. As a consequence, the mixing layer, that is the first vertical layer above the surface in which mixing is efficient, is characterized by daily oscillations (e.g. Legrand et al., 2009). An assessment of the height and dynamics of the mixing layer can be inferred using a regional climatic model over the Antarctic continent. The MAR model simulations (Gallee and Schayes, 1994; Gallee, 1995) are validated through observations from weather stations at DC (Gallee and Gorodetskaya, 2010).

\section{Results}

\subsection{First observations of a diurnal cycling of $\mathbf{H g}^{\mathbf{0}}$ in the boundary layer of the Antarctic Plateau}

As presented in Fig. $2, \mathrm{Hg}^{0}$ concentrations in the lower troposphere of DC varied from $0.2 \mathrm{ng} \mathrm{m}^{-3}$ to $2.3 \mathrm{ng} \mathrm{m}^{-3}$ (mean of $0.85 \pm 0.46 \mathrm{ng} \mathrm{m}^{-3}$ ). Our data were in the range of values retrieved during the same season at coastal Antarctic sites such as Neumayer Station $\left(\sim 1 \mathrm{ng} \mathrm{m}^{-3}\right.$ for Total Gaseous Mercury, Ebinghaus et al., 2002), Terra Nova Bay $\left(0.9 \pm 0.3 \mathrm{ng} \mathrm{m}^{-3}\right.$ Sprovieri et al., 2002), McMurdo $\left(1.20 \pm 1.08 \mathrm{ng} \mathrm{m}^{-3}\right.$ Brooks et al., 2008b) or at the Norwegian Antarctic Research Station, Troll $\left(0.93 \pm 0.19 \mathrm{ng} \mathrm{m}^{-3}\right.$ Pfaffhuber et al., 2012). During the single study ever 
published carried out with modern instruments on the Antarctic plateau, Brooks et al. (2008a) reported $\mathrm{Hg}^{0}$ values of $0.54 \pm 0.19 \mathrm{ng} \mathrm{m}^{-3}$ at South Pole station in NovemberDecember. While both Antarctic plateau sites showed comparable low values, our study additionally revealed that $\mathrm{Hg}^{0}$ exhibited significant and daily cycling. As presented in Fig. $3, \mathrm{Hg}^{0}$ concentrations were usually minimal around 00:00. Atmospheric $\mathrm{Hg}^{0}$ reached maximal concentrations around noon with high values for such a remote place. High day-to-day fluctuations were also observed. For example, the average $\mathrm{Hg}^{0}$ concentration was $1.25 \pm 0.45 \mathrm{ng} \mathrm{m}^{-3}$ on 2324 January, and $0.29 \pm 0.15 \mathrm{ng} \mathrm{m}^{-3}$ on 28 January. As shown in Fig. 2, where 30-min averaged $\mathrm{O}_{3}$ mixing ratios at $\mathrm{DC}$ are reported, a negative correlation between $\mathrm{Hg}^{0}$ and $\mathrm{O}_{3}$ was observed during our field campaign without any dramatic depletion of $\mathrm{O}_{3}$ at any time. At a daily scale, the $\mathrm{O}_{3}$ level reached its maximum around midnight when $\mathrm{Hg}^{0}$ was minimum. The highest levels for $\mathrm{O}_{3}$ (between 26 and 31 ppbv) were observed on 22,25 and 28 January around midnight when $\mathrm{Hg}^{0}$ was depleted below $0.3 \mathrm{ng} \mathrm{m}^{-3}$.

\section{2 $\mathrm{Hg}^{0}$ in the snow interstitial air}

The evolution in time of $\mathrm{Hg}^{0}$ concentrations in the snow interstitial air (SIA) is presented in Fig. 4. During the campaign, we observed a decrease in the mean $\mathrm{Hg}^{0}$ concentration in the SIA with depth. Depths of 40 and $80 \mathrm{~cm}$ exhibited higher concentrations than ambient ones while $\mathrm{Hg}^{0}$ concentrations deeper in the snow $(120$ and $160 \mathrm{~cm})$ were below ambient air values. At South Pole, Brooks et al. (2008a) reported $\mathrm{Hg}^{0}$ concentrations peaking at $3 \mathrm{ng} \mathrm{m}^{-3}$ at a depth of $3 \mathrm{~cm}$ indicating that the upper snow layer produced $\mathrm{Hg}^{0}$. SIA measurements clearly showed diel variation with minimum concentrations at night and maximum concentrations during day hours. SIA measurement patterns mirrored ambient value oscillations with maxima of 5.0 and $4.5 \mathrm{ng} \mathrm{m}^{-3}$ on 24 and 25 January, respectively. The amplitude of variations appeared to be smaller in the SIA than in the ambient air as we sampled deeper in the snowpack.

\subsection{Total Hg in the snow}

THg concentrations between DC and Dumont d'Urville were in the range $4.2-194.4 \mathrm{ng} \mathrm{L}^{-1}$ (mean value $47.0 \mathrm{ng} \mathrm{L}^{-1}$ ). The closest sample from DC (collected $131 \mathrm{~km}$ away) showed a THg concentration of $60.3 \pm 8.1 \mathrm{ng} \mathrm{L}^{-1}(n=3)$. These levels were higher than background values as encountered in Antarctic ice cores (Planchon et al., 2004) and in agreement with the surface snow average of $198 \mathrm{ng} \mathrm{L}^{-1}$ at South Pole (Brooks et al., 2008a).

\subsection{Influence of local meteorological conditions on $\mathrm{Hg}^{0}$ measurements}

Using MAR simulations (see Sect. 2.3), we calculated that the mixing layer could be very thin at night (around $20 \mathrm{~m}$ ) as

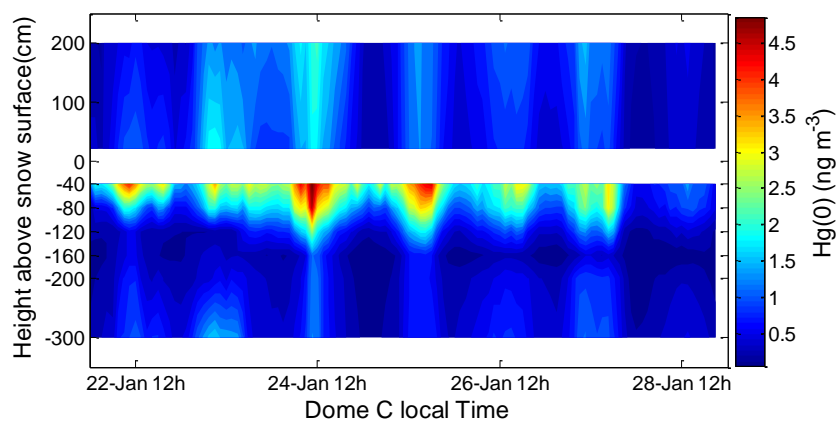

Fig. 4. Time series of $\mathrm{Hg}^{0}$ concentrations measured above and below the snow.

shown in Fig. 5c. Night time vertical mixing was limited to the first $20 \mathrm{~m}$ of the low troposphere that was confined and isolated from the overlying atmospheric layers. $\mathrm{Hg}^{0}$ measurements around midnight thus provided information on the $\mathrm{Hg}^{0}$ behavior at the air-snow interface. During day hours, the vertical mixing was greater and the mixing layer could increase up to a height of $250 \mathrm{~m}$ resulting in an efficient air mixing from the snow surface to higher altitudes in the troposphere.

To further understand these physical phenomena, measurements of the vertical temperature profiles are useful since turbulence redistributes temperature in the mixing layer. As presented in Fig. 5a, the absence of temperature gradients indicated the existence of an active vertical mixing of the chemical species in the first $41.9 \mathrm{~m}$ of the troposphere at least. These conditions coincided with increasing $\mathrm{Hg}^{0}$ concentrations. When a vertical gradient of temperature was measured, it indicated the occurrence of stratified conditions and the absence of vertical mixing for $\mathrm{Hg}^{0}$, the lowest temperatures being at the air-snow interface. These conditions were usually observed during night hours and corresponded to an abrupt decrease of atmospheric $\mathrm{Hg}^{0}$ concentrations. The night hours between 23 and 24 January were the only ones that showed no wind and no temperature stratification due to the occurrence of higher temperatures during that night. However, such conditions were still those of a stable atmosphere with limited vertical mixing. During that night, the typical $\mathrm{Hg}^{0}$ decrease was not observed and the concentrations remained roughly constant around $1.2 \mathrm{ng} \mathrm{m}^{-3}$.

\section{Discussion}

The interpretation of atmospheric $\mathrm{Hg}^{0}$ measurements at DC is very complex considering the lack of detailed knowledge of both atmospheric composition and the various physicochemical phenomena that are likely involved. Among possible mechanisms that drive the dynamics of $\mathrm{Hg}^{0}$ variations at a daily scale, the impact of local meteorological conditions such as the vertical mixing, the role of the snowpack as a 
source of $\mathrm{Hg}^{0}$ and the atmospheric loss of $\mathrm{Hg}^{0}$ by oxidation processes deserve further discussion.

\subsection{Snow as an intense source of $\mathbf{H g}^{\mathbf{0}}$}

As shown in Fig. $4, \mathrm{Hg}^{0}$ concentrations in the snow interstitial air exceeded ambiant concentrations. Although intrumentation was not sufficient to calculate $\mathrm{Hg}^{0}$ fluxes, this indicates that upper layers of the snowpack were a source of atmopheric $\mathrm{Hg}^{0}$.

\subsubsection{Air-snow physical exchange of $\mathrm{Hg}^{\mathbf{0}}$ ?}

There was a striking positive correlation between atmospheric $\mathrm{Hg}^{0}$ and air temperature (see Fig. 5). It could be due to the adsorption equilibrium of $\mathrm{Hg}^{0}$ on snow crystals: as temperature rises, $\mathrm{Hg}^{0}$ is released to the gas phase. However, the adsorption of $\mathrm{Hg}^{0}$ on the snow surface is very weak with a partition coefficient (i.e. the ratio between adsorbed molecules per $\mathrm{cm}^{2}$ and the concentration in the gas phase expressed in molecules $\mathrm{cm}^{-3}$ ) $K_{\text {linC }}$ in the $10^{-4} \mathrm{~cm}$ range at $240 \mathrm{~K}$ (Bartels-Rausch et al., 2008). This means that 300 atoms of $\mathrm{Hg}$ only would be adsorbed per $\mathrm{cm}^{2}$ of ice given an average atmospheric $\mathrm{Hg}^{0}$ concentration of $1 \mathrm{ng} \mathrm{m}^{-3}$. If we assume that the first $10 \mathrm{~cm}$ of the snowpack are in equilibrium with the atmospheric boundary layer and consider a snow specific surface area of $30 \mathrm{~m}^{2} \mathrm{~kg}^{-1}$ and a snow density of $300 \mathrm{~kg} \mathrm{~m}^{-3}$ (Gallet et al., 2011), we calculate that the upper $10 \mathrm{~cm}$ of the snowpack only contained about $10^{-4} \mathrm{ng}$ of adsorbed $\mathrm{Hg}$ per square meter of ground surface. This very low value is not sufficient to explain $\mathrm{Hg}^{0}$ variations of about 1 to $2 \mathrm{ng} \mathrm{m}^{-3}$ observed above the snowpack. Adsorption and desorption processes of $\mathrm{Hg}^{0}$ on snow grains cannot therefore account for the $\mathrm{Hg}^{0}$ variations at DC.

\subsubsection{Snow as a photochemical source of $\mathrm{Hg}^{\mathbf{0}}$}

Photoreduction of previously deposited $\mathrm{Hg}$ (II) has been observed both in the field and in laboratory experiments with snow from diverse origins (for a review, refer to Durnford and Dastoor, 2011). Now, how can $\mathrm{Hg}^{0}$ production in the snow lead to such high atmospheric levels? A rapid calculation using a snow density of $300 \mathrm{~kg} \mathrm{~m}^{-3}$ shows that a loss of $6 \mathrm{ng} \mathrm{L}^{-1}$ of $\mathrm{Hg}$ (II) from the top $10 \mathrm{~cm}$ of the snowpack would lead to a homogeneous concentration increase of $0.9 \mathrm{ng} \mathrm{m}^{-3}$ in a mixing layer of $200 \mathrm{~m}$ high. Assuming an emission duration of $12 \mathrm{~h}$, the resulting $\mathrm{Hg}^{0}$ flux from the snowpack would be $15 \mathrm{ng} \mathrm{m}^{-2} \mathrm{~h}^{-1}$. By comparison, an $\mathrm{Hg}^{0}$ flux of $10 \mathrm{ng} \mathrm{m}^{-2} \mathrm{~h}^{-1}$ over a 16-hour time period was measured in mid November 2003 from Antarctic snow at South Pole (Brooks et al., 2008a) when solar radiation was lower than in our study. Therefore, the increase in $\mathrm{Hg}^{0}$ concentration in ambient air can be explained by the photoreduction of $\mathrm{Hg}$ (II) species in the active photic zone of the snowpack. This is consistent with the elevated concentrations measured in the SIA and compatible with previously observed $\mathrm{Hg}^{0}$ fluxes at
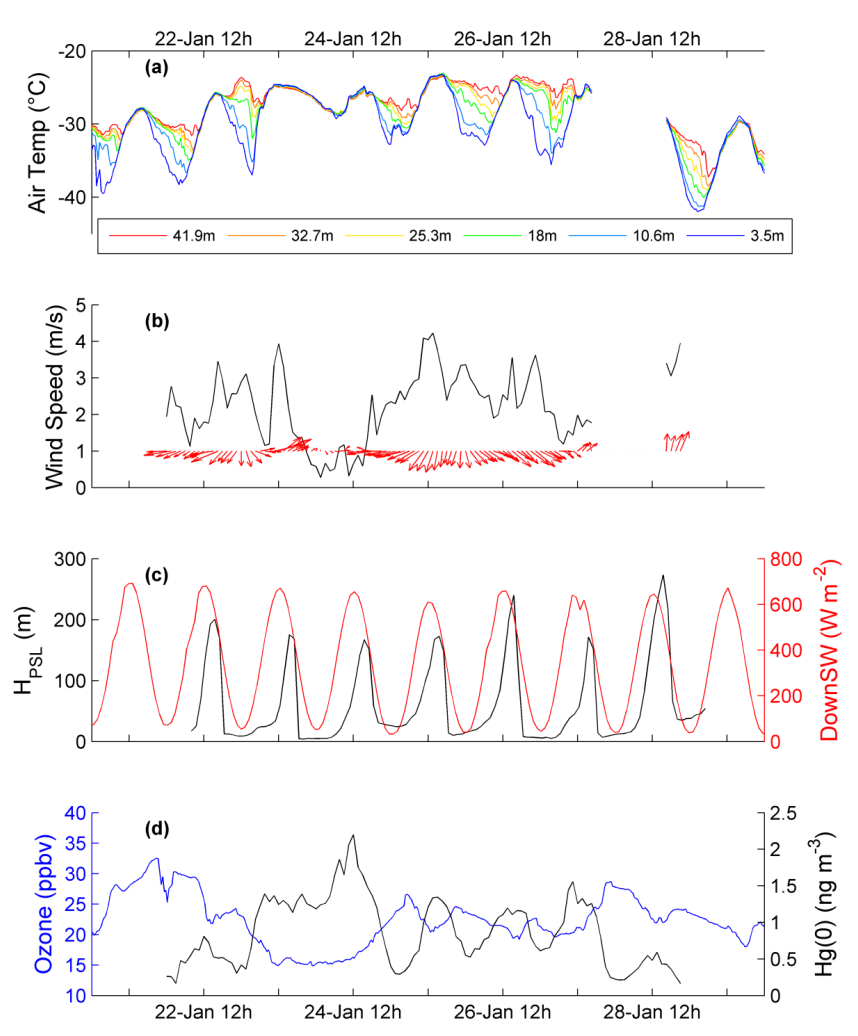

Fig. 5. Time series of (a) air temperature measured at different heights (b) wind speed (black line) and direction (red arrows) (c) boundary layer height (black line) as calculated by MAR and downward shortwave radiation (red line) (d) ozone and $\mathrm{Hg}^{0}$ concentrations.

the air/snowpack interface of Antarctic regions. The amplitude of $\mathrm{Hg}^{0}$ emissions may also be driven by atmospheric conditions. Boundary layer dynamics, turbulence and wind pumping affect these emissions and their transport in the atmosphere.

\subsection{Daily "night-time" depletion of atmospheric $\mathrm{Hg}^{0}$}

\subsubsection{Hypothesis on a local reactivity}

Episodic decreases of atmospheric $\mathrm{Hg}^{0}$ were reported in all the records of Antarctic sites during the spring or the summer. Negative correlation between $\mathrm{Hg}^{0}$ and ozone were also observed (Ebinghaus et al., 2002; Sprovieri et al., 2002; Temme et al., 2003; Pfaffhuber et al., 2012). In a modeling study, Holmes et al. (2006) proposed that subsiding air from the free troposphere above the mixing layer could bring to the surface gaseous $\mathrm{Hg}$ (II) formed by reaction with bromine radicals together with elevated ozone. Holmes et al. (2010) found that these events could fit data collected at Neumayer (Temme et al., 2003). A recent study held at the Norwegian Antarctic Research Station, Troll (220 km from the coast) suggests that low $\mathrm{Hg}^{0}$ with high $\mathrm{O}_{3}$ recorded in summer can 
be explained by these subsidence events occurring on the Plateau and transported to their site (Pfaffhuber et al., 2012).

Our measurements were conducted on the Plateau during a period when transport was limited. We also think that subsidence events were very unlikely.

Firstly, our model simulations and measurements of temperature gradients demonstrated the existence of a shallow mixing layer during low irradiation periods that coincided with an average dramatic decrease of $\mathrm{Hg}^{0}$ together with $\mathrm{O}_{3}$ increase after 04:00 p.m. (Fig. 5). The progressive thermal stratification that occurred after 03:00 p.m. due to the cooling of the snow surface created a very stable layer that strongly limited exchanges between the night-time boundary layer and the free troposphere. It implies that the $\mathrm{Hg}^{0}$ loss that we observed should not be due to dilution with $\mathrm{Hg}^{0}$-depleted air masses from above. It may result from local processes occurring within the mixing layer above the snow surface. As the mixing layer gets thinner, $\mathrm{Hg}^{0}$ reached the lowest levels and therefore reinforces the idea that the processes that were responsible for the $\mathrm{Hg}^{0}$ loss occurred near the surface.

Secondly, local photochemistry is an important source of $\mathrm{O}_{3}$ during the summer months in central Antarctica. It has been shown at South Pole (Davis et al., 2008) and later at DC (Frey et al., 2012) that the photo-denitrification of surface snow is responsible for high $\mathrm{NO}_{\mathrm{x}}$ levels during the summer. High $\mathrm{NO}_{\mathrm{x}}$ summer levels significantly modulate the ozone cycling (Crawford et al., 2001; Legrand et al., 2009; Slusher et al., 2010). Net $\mathrm{O}_{3}$ production occurs when the rate of production via $\mathrm{NO}_{2}$ photolysis exceeds the rate of photochemical destruction by NO in the Leighton cycle (Leighton, 1961). We think that $\mathrm{O}_{3}$ increases at $\mathrm{DC}$ were a consequence of $\mathrm{NO}_{\mathrm{x}}$ photochemistry occurring in the mixing layer. Therefore, $\mathrm{O}_{3}$ increases that were measured at other Antarctic sites when $\mathrm{Hg}^{0}$ was low (Ebinghaus et al., 2002; Sprovieri et al., 2002; Temme et al., 2003; Pfaffhuber et al., 2012) likely resulted from $\mathrm{NO}_{\mathrm{x}}$ photochemistry that occurs on the Antarctic plateau during summer.

Although high altitude vertical profiles of $\mathrm{Hg}^{0}$ should be done to further explore these assumption, we suggest that $\mathrm{Hg}^{0}$ decreases were confined in the mixing layer at DC and could result from surface or snow-induced processes.

\subsubsection{Examining oxidation pathways with halogens}

The very fast $\mathrm{Hg}^{0}$ decrease that we observed requires the presence of efficient oxidants. According to our current understanding of gas phase chemistry of $\mathrm{Hg}^{0}, \mathrm{Br}$ or $\mathrm{BrO}$ are relevant oxidants that could significantly decrease the lifetime of $\mathrm{Hg}^{0}$ (Ariya et al., 2004). Both $\mathrm{NO}_{\mathrm{x}}$ and $\mathrm{O}_{3}$ chemistry would be impacted by the presence of halogens. The oxidation reaction for $\mathrm{Hg}^{0}$ could be a two-step mechanism with a first step leading to an unstable $\mathrm{HgBr}$ radical (Goodsite et al., 2004). $\mathrm{HgBr}$ would further react with $\mathrm{Br}, \mathrm{OH}$, or $\mathrm{O}_{3}$ to form $\mathrm{Hg}$ (II) products that are subsequently incorporated into snow. Reactions of $\mathrm{HgBr}$ with $\mathrm{NO}_{2}, \mathrm{HO}_{2}, \mathrm{ClO}$ and $\mathrm{BrO}$ could be more important than with $\mathrm{Br}$ and $\mathrm{OH}$ as recently suggested by Dibble et al. (2012). Among these oxidants, $\mathrm{NO}_{2}$ is particularly abundant at DC (Frey et al., 2012). Given the temperature dependencies of these reactions, lower temperatures at night could decrease the lifetime of $\mathrm{Hg}^{0}$.

The lack of halogen measurements in the Antarctic plateau makes it difficult to assess the possible role of halogens at DC. In the following, we propose some potential sources.

1. At DC, winter storms can transport marine species including halogens to the Plateau (Jourdain et al., 2008) and sea spray significantly contributes to aerosol ion mass at DC, especially in the winter (Udisti et al., 2012). We could not find any evidence of transport of marine air masses during our field campaign by computing back-trajectories using HYSPLIT (Draxler and Rolph, 2003).

2. As shown by cosmogenic tracers, influxes of stratospheric air into the troposphere regularly occur during winter time (Wagenbach et al., 1998). These stratospheric inputs were discovered at DC in the winter (July-September) by studying the isotopic composition $\left(\Delta^{17} \mathrm{O}\right)$ of atmospheric particulate nitrate (Frey et al., 2009) and cannot be ruled out later in the season since the photolytic recycling of nitrate above snow alters the isotopic signature of the stratosphere. Sedimentation of $\mathrm{Hg}(\mathrm{II})$-halogen particles (Lyman and Jaffe, 2012) that are produced in the lower stratosphere (Murphy et al., 1998, 2006) could explain an initial source of both $\mathrm{Hg}(\mathrm{II})$ and halogens in the snow. The fate of such particles once deposited in snow is uncertain, but the photolytic reaction of $\mathrm{Hg}$ (II)-halogen species could potentially lead not only to the emission of photo-reduced $\mathrm{Hg}^{0}$ but also of activated halogens in the gas phase.

3. Measurable levels of $\mathrm{BrO}$ (typically between 1 and $3 \mathrm{ppt}_{\mathrm{v}}$ ) were recently detected in the atmosphere of Summit over the Greenland ice sheet $400 \mathrm{~km}$ from the ocean and in air masses not originating from the sea (Stutz et al., 2011). Brooks et al. (2011) concluded to the existence of bromine and mercury chemistry. It was suggested that snowpack photochemistry could be a possible source of $\mathrm{BrO}$ to the atmosphere (Dibb et al., 2010; Stutz et al., 2011). However the sources of bromide remained unclear and could be the falling snow and the transport of some bromine species from the free troposphere or marine regions.

There are currently no measurements of $\mathrm{Br}^{-}$in the snow nor of reactive bromine species in the atmosphere of DC or other central Antarctic places to support that there is an active chemistry involving $\mathrm{Hg}^{0}$ and halogens. Field measurements of $\mathrm{Br} / \mathrm{BrO}$ mixing ratios need to be performed to support this hypothesis. 


\subsubsection{Other potential chemical pathways}

Summer photochemistry is very active on the Antarctic Plateau leading to high concentrations of oxidants that could influence the lifetime of $\mathrm{Hg}^{0}$. OH concentrations can reach several $10^{6}$ molecules $\mathrm{cm}^{-3}$ (Davis et al., 2008), $\mathrm{NO}_{\mathrm{x}}$ are abundant and many nitrogen-related compounds such as nitric acid (Huey et al., 2004), nitrous acid - that was recently showed to peak in the atmosphere at DC in the evening (Kerbrat et al., 2012) - could be potential $\mathrm{Hg}^{0}$ oxidants. Hydrogen peroxide was noticeably present in South Pole snow that is considered to be a strong $\mathrm{H}_{2} \mathrm{O}_{2}$ source in the summer (Hutterli et al., 2004). Peroxy radicals should be abundant as suggested by Frey et al. (2012). However, gas phase kinetics of $\mathrm{Hg}^{0}$ oxidation with these oxidants are not fast enough to support our observations.

Because the mixing layer was very shallow at night, the influence of snowpack chemistry on measured atmospheric concentration was overwhelmed and may indicate that the removal of atmospheric $\mathrm{Hg}^{0}$ involved snow mediated processes such as heterogeneous chemistry.

Heterogeneous reactions occur in clouds, in the presence of particles and on snow surfaces (Dominé and Shepson, 2002). They play an important role on the tropospheric chemistry. For instance, Clegg and Abbatt (2001) experimentally measured the kinetics of $\mathrm{SO}_{2}$ oxidation by $\mathrm{H}_{2} \mathrm{O}_{2}$ on ice surfaces. The reaction was found to be fast enough to determine the lifetime of $\mathrm{SO}_{2}$ in clouds, making the gas phase oxidation by $\mathrm{OH}$ a minor process.

A recent review of $\mathrm{Hg}$ atmospheric chemistry reminds us both the importance and the lack of knowledge on heterogeneous reactions involving gaseous mercury (Subir et al., 2011, 2012). A recent study showed that freezing an acidic solution containing nitrite or hydrogen peroxide can oxidize dissolved elemental mercury in the dark (O'Concubhair et al., 2012). Similar processes could occur at DC in the snow or on surface hoar during low irradiation periods, which fits well with the observed decrease in $\mathrm{Hg}^{0}$ concentrations. Many oxidants that are present at DC could be involved such as nitrous acid or hydrogen peroxide.

Oxidation products such as $\mathrm{Hg}$ (II) species could strongly interact with snow surfaces leading to more efficient oxidation pathways. Among other unclear processes, the very low levels of $\mathrm{Hg}^{0}$ in the lower interstitial air of the snowpack (Fig. 4) raise the question of the fate of $\mathrm{Hg}^{0}$ in the firn and suggest a possible dark oxidation of $\mathrm{Hg}^{0}$. The same pattern was observed in other snowpacks in the Arctic (Maron et al., 2008). Similar decreasing concentrations in the deeper interstitial air were also observed for ozone at Alert in Canada (Albert et al., 2002) or at Summit in Greenland (Peterson and Honrath, 2001; Helmig et al., 2009). So far, no mechanisms have been validated for $\mathrm{O}_{3}$ and $\mathrm{Hg}$.

\section{Conclusions}

This second study on an Antarctic inland site highlights both the spatial variability and the complexity of chemical pathways involved in $\mathrm{Hg}$ reactivity. At $\mathrm{DC}, \mathrm{Hg}^{0}$ was negatively correlated with $\mathrm{O}_{3}$ mixing ratios and followed high daily fluctuations.

Both atmospheric and interstitial air measurements suggested an intense production of $\mathrm{Hg}^{0}$ from the photoreduction of $\mathrm{Hg}$ (II) species in snow. When the solar radiation generated active vertical turbulence during daytime, the mixing layer height increased rapidly together with $\mathrm{Hg}^{0}$ levels that reached unexpectedly high concentrations for such a remote place.

To sustain the observed daily cycles of $\mathrm{Hg}^{0}$, a reservoir of $\mathrm{Hg}$ (II) in snow is needed. We speculated that $\mathrm{Hg}$ (II) species could be deposited in the snow as a result of fast oxidation processes involving $\mathrm{Hg}^{0}$. Our atmospheric measurements and the modeling of the atmospheric boundary layer height showed the existence of a dramatic and daily removal of $\mathrm{Hg}^{0}$ during low irradiation periods in a confined mixing layer. Unlike other Antarctic studies, the advection of $\mathrm{Hg}^{0}$-depleted air masses seemed unlikely at DC. Based on our current knowledge of gas phase chemistry, oxidation by halogen species (such as bromine) could not be ruled out although there is no evidence of bromine chemistry at DC to date.

Because the recycling of nitrogen species in the Antarctic plateau has been shown to present similar pathways that our observed $\mathrm{Hg}$ cycles, we suggest that the observation of $\mathrm{Hg}^{0}$ losses may include heterogeneous chemistry with compounds such as $\mathrm{HONO}, \mathrm{H}_{2} \mathrm{O}_{2}$ or $\mathrm{HNO}_{3}$. Detailed kinetic studies of multiphasic $\mathrm{Hg}^{0}$ oxidation using ice/snow surfaces are not available yet. We believe that our observations should motivate further studies to identify processes involved in the cycling of $\mathrm{Hg}$ in the Antarctic plateau. Although the photoreduction of $\mathrm{Hg}(\mathrm{II})$ species in snow and the release of $\mathrm{Hg}^{0}$ from the snowpack are well documented, there are still serious shortcomings in how we can explain the fast oxidation processes observed above and probably inside the snowpack.

Considering the large surface and the $\mathrm{Hg}$ amounts stored on the Antarctic continent, these phenomena could play an important role at a regional scale. However, quantifying their impact is complex because the seasonality of $\mathrm{Hg}$ chemistry in the Antarctic has not been studied yet. The winter cycle of $\mathrm{Hg}^{0}$ on the Antarctic Plateau will be explored in the close future but we speculate that $\mathrm{Hg}^{0}$ reactivity could be far less pronounced due to the absence of light during long periods.

Acknowledgements. This work was funded by the ANR VMC VANISH (project ANR-07-VULN-013). Field logistic supplies and some financial support were provided by the French Polar Institute (IPEV) through programs Glaciologie 902 and GMOstral 1028. We particularly acknowledge the support of our late lamented colleague Jean-Marc Barnola. Wind and temperature tower observations were kindly provided by C. Genthon. Support by the CALVA programme 
(IPEV 1013, http://lgge.osug.fr/ christo/calva/home.shtml) and OSUG CENACLAM observatory is acknowledged. The MAR simulations were run on CNRS/IDRIS and Université Joseph Fourier CIMENT computers. The authors gratefully acknowledge Philippe Possenti, Laurent Arnaud, Jérôme Chappellaz, Bruno Jourdain and Emmanuel Le Meur for their support before and during the campaign. AD acknowledges the Institut Universitaire de France.

Edited by: A. Dastoor

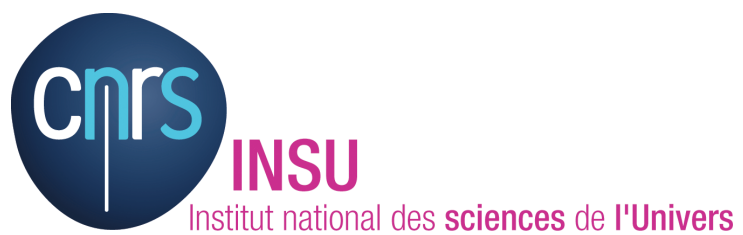

The publication of this article is financed by CNRS-INSU.

\section{References}

Albert, M. R., Grannas, A. M., Bottenheim, J., Shepson, P. B., and Perron Jr., F. E.: Processes and Properties of Snow-Air Transfer in the High Arctic with Application to Interstitial Ozone at Alert, Canada, Atmos. Environ., 36, 2779-2787, 2002.

Ariya, P. A., Dastoor, A. P., Amyot, M., Schroeder, W. H., Barrie, L., Anlauf, K., Raofie, F., Ryzhkov, A., Davignon, D., Lalonde, J., and Steffen, A.: The Arctic: a sink for mercury, Tellus B, 56, 397-403, 2004.

Bartels-Rausch, T., Huthwelker, T., Jöri, M., Gäggeler, H. W., and Ammann, M.: Interaction of gaseous elemental mercury with snow surfaces: laboratory investigation, Environmental. Res. Lett., 3, 045009, doi:10.1088/1748-9326/3/4/045009, 2008.

Brooks, S., Arimoto, R., Lindberg, S., and Southworth, G.: Antarctic polar plateau snow surface conversion of deposited oxidized mercury to gaseous elemental mercury with fractional long-term burial, Atmos. Environ., 42, 2877-2884, 2008a.

Brooks, S., Lindberg, S., Southworth, G., and Arimoto, R.: Springtime atmospheric mercury speciation in the McMurdo, Antarctica coastal region, Atmos. Environ., 42, 2885-2893, doi:10.1016/j.atmosenv.2007.06.038, 2008b.

Brooks, S., Moore, C., Lew, D., Lefer, B., Huey, G., and Tanner, D.: Temperature and sunlight controls of mercury oxidation and deposition atop the Greenland ice sheet, Atmos. Chem. Phys., 11, 8295-8306, doi:10.5194/acp-11-8295-2011, 2011.

Clegg, S. M. and Abbatt, J. P. D.: Oxidation of $\mathrm{SO} 2$ by $\mathrm{H}_{2} \mathrm{O}_{2}$ on ice surfaces at $228 \mathrm{~K}$ : a sink for $\mathrm{SO}_{2}$ in ice clouds, Atmos. Chem. Phys., 1, 73-78, doi:10.5194/acp-1-73-2001, 2001.

Crawford, J. H., Davis, D. D., Chen, G., Buhr, M., Oltmans, S., Weller, R., Mauldin, L., Eisele, F., Shetter, R., Lefer, B., Arimoto, R., and Hogan, A.: Evidence for photochemical production of ozone at the South Pole surface, Geophys. Res. Lett., 28, doi:10.1029/2001GL013055, 3641-3644, 2001.

Davis, D. D., Seelig, J., Huey, G., Crawford, J., Chen, G., Wang, Y., Buhr, M., Helmig, D., Neff, W., Blake, D., Arimoto, R., and Eisele, F.: A reassessment of Antarctic plateau reactive nitrogen based on ANTCI 2003 airborne and ground based measurements, Atmos. Environ., 42, 2831-2848, 2008.

Dibb, J. E., Ziemba, L. D., Luxford, J., and Beckman, P.: Bromide and other ions in the snow, firn air, and atmospheric boundary layer at Summit during GSHOX, Atmos. Chem. Phys., 10, 99319942, doi:10.5194/acp-10-9931-2010, 2010.

Dibble, T. S., Zelie, M. J., and Mao, H.: Thermodynamics of reactions of $\mathrm{ClHg}$ and $\mathrm{BrHg}$ radicals with atmospherically abundant free radicals, Atmos. Chem. Phys., 12, 10271-10279, doi:10.5194/acp-12-10271-2012, 2012.

Dominé, F. and Shepson, P. B.: Air-Snow Interactions and Atmospheric Chemistry, Science, 297, 1506-1510, 2002.

Dommergue, A., Ferrari, C. P., and Boutron, C. F.: First investigation of an original device dedicated to the determination of gaseous mercury in interstitial air in snow, Anal. Bioanal. Chem., 375, 106-111, 2003a.

Dommergue, A., Ferrari, C. P., Poissant, L., Gauchard, P. A., and Boutron, C. F.: Diurnal cycles of gaseous mercury within the snowpack at Kuujjuarapik/Whapmagoostui, Quebec, Canada, Environ. Sci. Technol., 37, 3289-3297, 2003b.

Dommergue, A., Sprovieri, F., Pirrone, N., Ebinghaus, R., Brooks, S., Courteaud, J., and Ferrari, C. P.: Overview of mercury measurements in the Antarctic troposphere, Atmos. Chem. Phys., 10, 3309-3319, doi:10.5194/acp-10-3309-2010, 2010.

Draxler, R. R. and Rolph, G. D.: HYSPLIT (HYbrid Single-Particle Lagrangian Integrated Trajectory) Model access via NOAA ARL READY Website(http://www.arl.noaa.gov/ready/hysplit4.html), NOAA Air Resources Laboratory, Silver Spring, MD, 2003.

Durnford, D. and Dastoor, A.: The behavior of mercury in the cryosphere: A review of what we know from observations, J. Geophys. Res.-Atmos., 116, D06305, doi:10.1029/2010jd014809, 2011.

Ebinghaus, R., Kock, H. H., Temme, C., Einax, J. W., Löwe, A. G., Richter, A., Burrows, J. P., and Schroeder, W. H.: Antarctic Springtime Depletion of Atmospheric Mercury, Environ. Sci. Technol., 36, 1238-1244, 2002.

Eisele, F., Davis, D. D., Helmig, D., Oltmans, S. J., Neff, W., Huey, G., Tanner, D., Chen, G., Crawford, J., Arimoto, R., Buhr, M., Mauldin, L., Hutterli, M., Dibb, J., Blake, D., Brooks, S. B., Johnson, B., Roberts, J. M., Wang, Y., Tan, D., and Flocke, F.: Antarctic Tropospheric Chemistry Investigation (ANTCI) 2003 overview, Atmos. Environ., 42, 2749-2761, 2008.

Frey, M. M., Savarino, J., Morin, S., Erbland, J., and Martins, J. M. F.: Photolysis imprint in the nitrate stable isotope signal in snow and atmosphere of East Antarctica and implications for reactive nitrogen cycling, Atmos. Chem. Phys., 9, 8681-8696, doi:10.5194/acp-9-8681-2009, 2009.

Frey, M. M., Brough, N., France, J. L., Traulle, O., Anderson, P. S., King, M. D., Jones, A. E., Wolff, E. W., and Savarino, J.: The diurnal variability of atmospheric nitrogen oxides (NO and $\mathrm{NO}_{2}$ ) above the Antarctic Plateau driven by atmospheric stability and snow emissions, Atmos. Chem. Phys. Discuss., 12, 22309 22353, doi:10.5194/acpd-12-22309-2012, 2012.

Gallee, H.: Simulation of the Mesocyclonic Activity in the Ross Sea, Antarctica, Mon. Weather Rev., 123, 2051-2069, 1995.

Gallee, H. and Gorodetskaya, I. V.: Validation of a limited area model over Dome C, Antarctic Plateau, during winter, Clim. Dynam., 34, 61-72, doi:10.1007/s00382-008-0499-y, 2010. 
Gallee, H. and Schayes, G.: Development of a 3-Dimensional Meso-Gamma Primitive Equation Model - Katabatic Winds Simulation in the Area of Terra-Nova Bay, Antarctica, Mon. Weather Rev., 122, 671-685, 1994.

Gallet, J.-C., Domine, F., Arnaud, L., Picard, G., and Savarino, J.: Vertical profile of the specific surface area and density of the snow at Dome C and on a transect to Dumont D'Urville, Antarctica - albedo calculations and comparison to remote sensing products, The Cryosphere, 5, 631-649, doi:10.5194/tc-5-6312011, 2011

Garratt, J. R.: The atmospheric boundary layer, Cambridge atmospheric and space science series, 1, edited by: Houghton, J. T., Rycroft, M. J., and Dessler, A. J., Cambridge University Press Cambridge, 316 pp., 1994.

Genthon, C., Town, M. S., Six, D., Favier, V., Argentini, S., and Pellegrini, A.: Meteorological atmospheric boundary layer measurements and ECMWF analyses during summer at Dome C, Antarctica, J. Geophys. Res.-Atmos., 115, D05104, doi:10.1029/2009jd012741, 2010.

Genthon, C., Gallée, H., Six, D., Grigioni, P., and Pellegrini, A.: Two years of atmospheric boundary layer observation on a 45$\mathrm{m}$ tower and modeling at Dome $\mathrm{C}$ on the Antarctic plateau, J. Geophys. Res., in review, 2012.

Goodsite, M. E., Plane, J. M. C., and Skov, H.: A theoretical study of the oxidation of $\mathrm{Hg}^{0}$ to $\mathrm{HgBr}_{2}$ in the troposphere, Environ. Sci. Technol., 38, 1772-1776, 2004.

Helmig, D., Cohen, L. D., Bocquet, F., Oltmans, S., Grachev, A., and Neff, W.: Spring and summertime diurnal surface ozone fluxes over the polar snow at Summit, Greenland, Geophys. Res. Lett., 36, L08809, doi:10.1029/2008gl036549, 2009.

Holmes, C. D., Jacob, D. J., and Yang, X.: Global lifetime of elemental mercury against oxidation by atomic bromine in the free troposphere, Geophys. Res. Lett., 33, L20808, doi:10.1029/2006GL027176, 2006.

Holmes, C. D., Jacob, D. J., Corbitt, E. S., Mao, J., Yang, X., Talbot, R., and Slemr, F.: Global atmospheric model for mercury including oxidation by bromine atoms, Atmos. Chem. Phys., 10, 12037-12057, doi:10.5194/acp-10-12037-2010, 2010.

Huey, L. G., Tanner, D. J., Slusher, D. L., Dibb, J. E., Arimoto, R., Chen, G., Davis, D., Buhr, M. P., Nowak, J. B., Mauldin Iii, R. L., Eisele, F. L., and Kosciuch, E.: CIMS measurements of $\mathrm{HNO}_{3}$ and $\mathrm{SO}_{2}$ at the South Pole during ISCAT 2000, Atmos. Environ., 38, 5411-5421, doi:10.1016/j.atmosenv.2004.04.037, 2004.

Hutterli, M. A., McConnell, J. R., Chen, G., Bales, R. C., Davis, D. D., and Lenschow, D. H.: Formaldehyde and hydrogen peroxide in air, snow and interstitial air at South Pole, Atmos. Environ., 38, 5439-5450, doi:10.1016/j.atmosenv.2004.06.003, 2004.

Jitaru, P., Gabrielli, P., Marteel, A., Plane, J. M. C., Planchon, F. A. M., Gauchard, P. A., Ferrari, C. P., Boutron, C. F., Adams, F. C., Hong, S., Cescon, P., and Barbante, C.: Atmospheric depletion of mercury over Antarctica during glacial periods, Nature Geosci., 2, 505-508, doi:10.1038/ngeo549, 2009.

Jourdain, B., Preunkert, S., Cerri, O., Castebrunet, H., Udisti, R., and Legrand, M.: Year-round record of size-segregated aerosol composition in central Antarctica (Concordia station): Implications for the degree of fractionation of sea-salt particles, J. Geophys. Res., 113, D14308, doi:10.1029/2007jd009584, 2008.

Kerbrat, M., Legrand, M., Preunkert, S., Gallée, H., and Kleffmann, J.: Nitrous acid at Concordia (inland site) and Dumont d'Urville (coastal site), East Antarctica, J. Geophys. Res., 117, D08303, doi:10.1029/2011jd017149, 2012.

Legrand, M., Preunkert, S., Jourdain, B., Gallée, H., Goutail, F., Weller, R., and Savarino, J.: Year-round record of surface ozone at coastal (Dumont d'Urville) and inland (Concordia) sites in East Antarctica, J. Geophys. Res., 114, D20306, doi:10.1029/2008JD011667, 2009.

Leighton, P. A.: Photochemistry of air pollution, Academic Press, New York, 300 pp., 1961.

Lyman, S. N. and Jaffe, D. A.: Formation and fate of oxidized mercury in the upper troposphere and lower stratosphere, Nature Geosci., 5, 114-117, doi:10.1038/ngeo1353, 2012.

Maron, L., Dommergue, A., Ferrari, C. P., Delacour-Larose, M., and Faïn, X.: How elementary mercury react in presence of halogen radicals and/or halogen anions: A DFT investigation, Chem. Eur. J., 14, 8322-8329, 2008.

Murphy, D. M., Thomson, D. S., and Mahoney, T. M. J.: In situ measurements of organics, meteoritic material, mercury, and other elements in aerosols at 5 to $19 \mathrm{~km}$, Science, 282, 1664-1669, 1998.

Murphy, D. M., Hudson, P. K., Thomson, D. S., Sheridan, P. J., and Wilson, J. C.: Observations of mercury-containing aerosols, Environ. Sci. Technol., 40, 3163-3167, 2006.

O'Concubhair, R., O'Sullivan, D., and Sodeau, J. R.: Dark Oxidation of Dissolved Gaseous Mercury in Polar Ice Mimics, Environ. Sci. Technol., 46, 4829-4836, doi:10.1021/es300309n, 2012.

Peterson, M. C. and Honrath, R. E.: Observations of rapid photochemical destruction of ozone in snowpack interstitial air, Geophys. Res. Lett., 28, 511-514, 2001.

Pfaffhuber, K. A., Berg, T., Hirdman, D., and Stohl, A.: Atmospheric mercury observations from Antarctica: seasonal variation and source and sink region calculations, Atmos. Chem. Phys., 12, 3241-3251, doi:10.5194/acp-12-3241-2012, 2012.

Planchon, F. A. M., Gabrielli, P., Gauchard, P. A., Dommergue, A., Barbante, C., Cairns, W. R. L., Cozzi, G., Nagorski, S. A., Ferrari, C. P., Boutron, C. F., Capodaglio, G., Cescon, P., Varga, A., and Wolff, E. W.: Direct determination of mercury at the subpicogram per gram level in polar snow and ice by ICP-SFMS, J. Anal. At. Spectrom., 19, 823-830, 2004.

Schwerdtfeger, W.: Weather and Climate of the Antarctic, Developments in Atmospheric Science No. 15, Elsevier, The Netherlands, 261 pp., 1984.

Selin, N. E., Jacob, D. J., Park, R. J., Yantosca, R. M., Strode, S., Jaegle, L., and Jaffe, D.: Chemical cycling and deposition of atmospheric mercury: Global constraints from observations, J. Geophys. Res., 112, D02308, doi:02310.01029/02006JD007450, 2007.

Slusher, D. L., Neff, W. D., Kim, S., Huey, L. G., Wang, Y., Zeng, T., Tanner, D. J., Blake, D. R., Beyersdorf, A., Lefer, B. L., Crawford, J. H., Eisele, F. L., Mauldin, R. L., Kosciuch, E., Buhr, M P., Wallace, H. W., and Davis, D. D.: Atmospheric chemistry results from the ANTCI 2005 Antarctic plateau airborne study, J. Geophys. Res., 115, D07304, doi:10.1029/2009jd012605, 2010.

Sprovieri, F., Pirrone, N., Hedgecock, I. M., Landis, M. S., and Stevens, R. K.: Intensive atmospheric mercury measurements at Terra Nova Bay in Antarctica during November and December 2000, J. Geophys. Res., 107, 4722, doi:10.1029/2002JD002057, 2002. 
Sprovieri, F., Pirrone, N., Ebinghaus, R., Kock, H., and Dommergue, A.: A review of worldwide atmospheric mercury measurements, Atmos. Chem. Phys., 10, 8245-8265, doi:10.5194/acp10-8245-2010, 2010.

Steffen, A., Douglas, T., Amyot, M., Ariya, P., Aspmo, K., Berg, T., Bottenheim, J., Brooks, S., Cobbett, F., Dastoor, A., Dommergue, A., Ebinghaus, R., Ferrari, C., Gardfeldt, K., Goodsite, M. E., Lean, D., Poulain, A. J., Scherz, C., Skov, H., Sommar, J., and Temme, C.: A synthesis of atmospheric mercury depletion event chemistry in the atmosphere and snow, Atmos. Chem. Phys., 8, 1445-1482, doi:10.5194/acp-8-1445-2008, 2008.

Stutz, J., Thomas, J. L., Hurlock, S. C., Schneider, M., von Glasow, R., Piot, M., Gorham, K., Burkhart, J. F., Ziemba, L., Dibb, J. E., and Lefer, B. L.: Longpath DOAS observations of surface BrO at Summit, Greenland, Atmos. Chem. Phys., 11, 9899-9910, doi:10.5194/acp-11-9899-2011, 2011.

Subir, M., Ariya, P. A., and Dastoor, A. P.: A review of uncertainties in atmospheric modeling of mercury chemistry I. Uncertainties in existing kinetic parameters - Fundamental limitations and the importance of heterogeneous chemistry, Atmos. Environ., 45, 5664-5676, doi:10.1016/j.atmosenv.2011.04.046, 2011.
Subir, M., Ariya, P. A., and Dastoor, A. P.: A review of the sources of uncertainties in atmospheric mercury modeling II, Mercury surface and heterogeneous chemistry - A missing link, Atmos. Environ., 46, 1-10, doi:10.1016/j.atmosenv.2011.07.047, 2012.

Temme, C., Einax, J. W., Ebinghaus, R., and Schroeder, W. H.: Measurements of Atmospheric Mercury Species at a Coastal Site in the Antarctic and over the South Atlantic Ocean during Polar Summer, Environ. Sci. Technol., 37, 22-31, 2003.

Udisti, R., Dayan, U., Becagli, S., Busetto, M., Frosini, D., Legrand, M., Lucarelli, F., Preunkert, S., Severi, M., Traversi, R., and Vitale, V.: Sea spray aerosol in central Antarctica. Present atmospheric behaviour and implications for paleoclimatic reconstructions, Atmos. Environ., 52, 109-120, doi:10.1016/j.atmosenv.2011.10.018, 2012.

Vandal, G. M., Fitzgerald, W. F., Boutron, C. F., and Candelone, J.: Variations in mercury deposition to Antarctica over the past 34000 years, Nature, 362, 621-623, 1993.

Wagenbach, D., Legrand, M., Fischer, H., Pichlmayer, F., and Wolff, E. W.: Atmospheric near-surface nitrate at coastal Antarctic sites, J. Geophys. Res.-Atmos., 103, 11007-11020, 1998. 